\title{
Development of water use scenarios as a tool for adaptation to climate change
}

\author{
R. Jacinto, M. J. Cruz, and F. D. Santos \\ CCIAM, SIM, Faculty of Sciences, University of Lisbon, C1, Sala 1.4.39, \\ Campo Grande, 1749-016 Lisbon, Portugal \\ Correspondence to: R. Jacinto (jacinto.rita@gmail.com)
}

Received: 2 May 2012 - Published in Drink. Water Eng. Sci. Discuss.: 28 June 2012 Revised: 22 April 2013 - Accepted: 23 May 2013 - Published: 21 June 2013

\begin{abstract}
The project ADAPTACLIMA, promoted by EPAL, the largest Portuguese Water Supply Utility, aims to provide the company with an adaptation strategy in the medium and long term to reduce the vulnerability of its activities to climate change. We used the four scenarios (A1, A2, B1, B2) adopted in the Special Report Emissions Scenarios (SRES) of the IPCC (Intergovernmental Panel on Climate Change) to produce local scenarios of water use. Available population SRES for Portugal were downscaled to the study area using a linear approach. Local land use scenarios were produced using the following steps: (1) characterization of the present land use for each municipality of the study area using Corine Land Cover and adaptation of the CLC classes to those used in the SRES; (2) identification of recent tendencies in land use change for the study area; (3) identification of SRES tendencies for land use change in Europe; and (4) production of local scenarios of land use. Water use scenarios were derived considering both population and land use scenarios as well as scenarios of change in other parameters (technological developments, increases in efficiency, climate changes, or political and behavioural changes).

The A2 scenario forecasts an increase in population $(+16 \%)$ in the study area while the other scenarios show a reduction in the resident population (-6 to $8 \%)$. All scenarios, but especially A1, show a reduction in agricultural area and an increase in urban area. Regardless of the scenario, water use will progressively be reduced until 2100. These reductions are mainly due to increased water use efficiency and the reduction of irrigated land. The results accord with several projects modelling water use at regional and global level.
\end{abstract}

\section{Introduction}

Climate change has already had effects on the natural environment and on socio-economic activities, and much bigger changes are projected for this century (IPCC, 2007; EEA, 2008). In Europe, especially in the south, water availability and water stress are already a concern (Henrichs et al., 2002; EEA, 2008). Climate change will further affect water availability and water consumption (EEA, 2008). Thus, there is a growing scientific and policy interest for water resources analyses on the global and regional scale (Märker et al., 2003; Menzel et al., 2007). Climate and socioeconomic drivers such as population and economic growth, land use and technological evolution, may have a great impact on water resources and stress (Menzel et al., 2007; Shen et al., 2008).

At the European level, several studies have looked into water resources availability and stress in the future (Henrichs et al., 2002; Mäerker et al., 2003; Menzel et al., 2007). However, the results differ between authors. Henrichs et al. (2002) projected a reduction in total water withdrawals in Western Europe and attributed that reduction to technological evolution and to households and industrial efficiency. Menzel et al. (2007) concluded that in Southern Europe the water stress and water withdrawals will increase due to irrigation demand and climate change.

In Portugal, there are published projections for the future population, such as the National Statistics Institute 


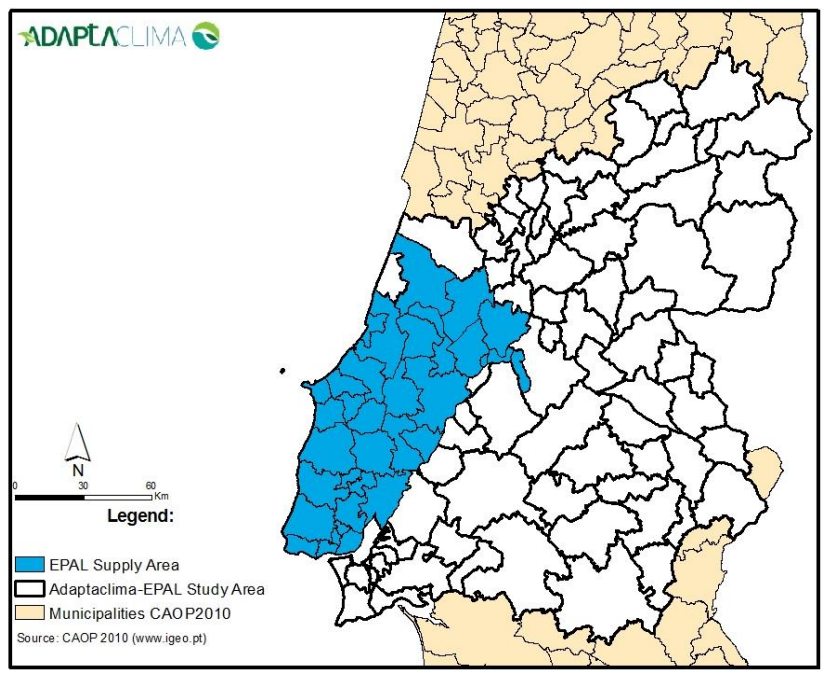

Figure 1. Study Area. Source: Adaptaclima-EPAL project report (2011).

projections made for the country up to the middle of the $21 \mathrm{st}$ century (INE, 2008) and the study "Climate change: Mitigation Strategies in Portugal" (MISP, 2007) with projections of the SRES scenarios downscaled for Portugal up to the end of the 21 st century.

The project ADAPTACLIMA-EPAL aims to provide socioeconomic scenarios for population growth, land use and water use for an area which includes the Portuguese basin of the Tagus River (Fig. 1) with all the municipalities that are supplied directly or indirectly by EPAL, and the west aquifers of continental territory of Portugal. In total, $106 \mathrm{mu}-$ nicipalities were included in the study area, of which, 34 are supplied by EPAL. Projections of future water withdrawals will contribute to EPAL, as well as to other stakeholders and policy makers. Other tasks of the project will include modelling future climate and water availability. All the generated data will be analysed and used to provide information to put in place a robust adaptation strategy to reduce vulnerability to future changes. In this paper future water stress for EPAL is evaluated by presenting socioeconomic scenarios for population growth, land use and water use for the project area.

\section{Materials and methods}

Local scenarios ${ }^{1}$ of water use until the end of the century were explored, not only for the EPAL system, but also for other sectors, namely agriculture or industry. We used the four IPCC SRES (A1, A2, B1 and B2) (IPCC, 2000) to produce climate and hydrological scenarios for the project. The IPCC SRES sets up changes in population, economic growth,

${ }^{1}$ The terminology local scenario was adopted for our results while for IPCC scenarios the term SRES was used. At the national scale, there are also INE's population projections. technology, energy consumption, and greenhouse gas emissions (IPCC, 2007; Shen et al., 2008). Several studies have produced water consumption scenarios for Europe for the 21 st century based on SRES (e.g. Seckler et al., 1998; Märker et al., 2003; Flörke et al., 2005; Alcamo et al., 2007; Bates et al., 2008; Shen et al., 2008; Kok et al., 2009).

Linear regionalization (Fig. 2) of the SRES for the study area was applied, because it is the most transparent and simple method available; it assumes that the evolution on the study area will be similar to the evolution on the biggest area (i.e. Portugal) (van Vuuren et al., 2007, 2010).

- Consistency with local observed data (for the historic or base period);

- Consistency with the original scenario (SRES scenarios);

- Transparency;

- Plausibility of the results.

The main steps of the methodology are summarised in Fig. 3. The evolution of water use depends on several factors such as population and land uses (e.g. Boland, 1998; Houghton-Carr et al., 2008). In addition, other parameters were taken into account, namely developments in technology, as well as changes in climate and consumer behaviour.

Downscaling methods transform worldwide, continental or country level scenarios on useful and applicable scenarios at more detailed scales of analysis. The downscaling for water use was done following three steps which are outlined below.

\subsection{Present water use by activity sector}

Data of water use per capita, by sector and municipality, was collected from the following sources: National Water Plan (INAG, 2001), Instituto Nacional de Estatistica (INE), EPAL (internal data for the period 2000-2010) and National Inventory of Water Supply Systems and Waste water (INSAAR, 2007).

\subsection{SRES scenarios - coefficients of change in demand factors}

The future water consumption was determined by demand factors. These factors are the following ones:

a. Population - The CIESIN (Center for International Earth Science Information Network), has developed a database containing regionalized SRES for population and GDP at the country scale (CIESIN, 2002). Using the population on the base year, from the National Statistics Institute (INE) estimated for 2005 (INE, 2006), local population scenarios for each municipality were built for the study area by applying the CIESIN growth rates 


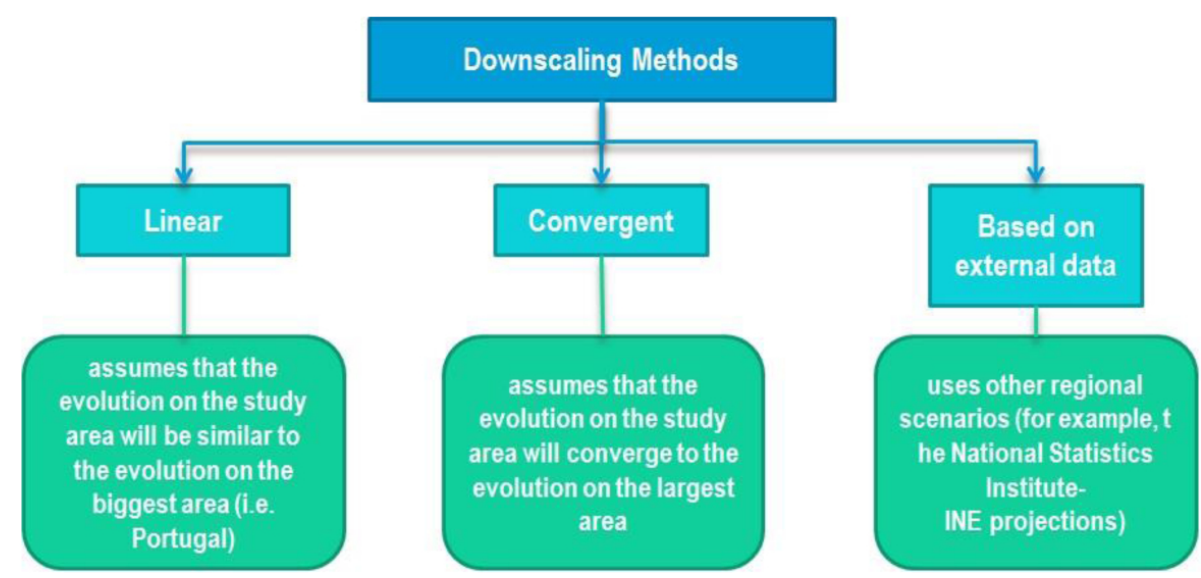

Figure 2. Downscaling methods in Socioeconomic Scenarios. Source: adapted from van Vuuren et al. (2010).
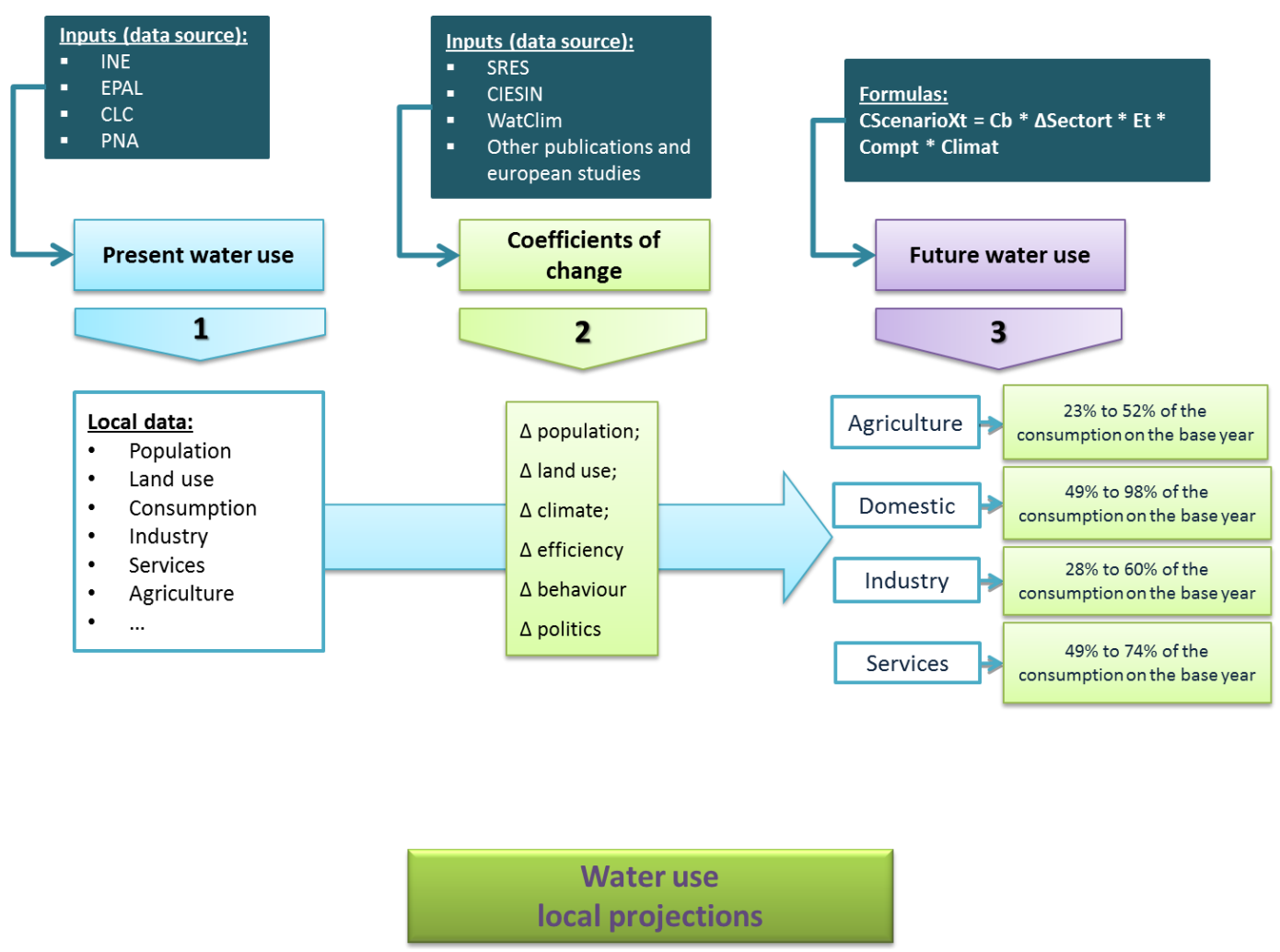

Figure 3. Resumed methodology for water withdrawals projections. Source: Adaptaclima-EPAL project report (2011).

downscaled for Portugal. Given the size of the study area and homogeneous characteristics in relation to the larger area, e.g. Portugal, the linear method of downscaling (O’Neill et al., 2001; Graffin et al., 2004) was considered the most appropriate;

b. Land use - Corine Land Cover land use classes were reclassified by grouping classes taking into consideration the classes used in SRES (Fig. 3). The sectors of water use considered in the National Water Plan (INAG,
2001) were taken into account. Local land use scenarios change (Fig. 4) in percentages for each municipality of the study area were produced by applying linear downscaling on the trends of the SRES scenarios for Europe and considering the characteristics of each county and the trends observed in recent years (IPCC, 2007; Schröter et al., 2005; Verburg et al., 2006; Rounsevell et al., 2006). Since Lisbon municipality is already almost only urban, the urban expansion for Lisbon municipality was redistributed to neighbouring municipalities. This 
Table 1. Main trends in the various forcing factors for water use for each scenario. Legend: $(+)$ indicates an increase, $(++)$ indicates a substantial increase, $(\approx)$ indicates no change or very small changes, $(-)$ indicates a decrease; $(--)$ indicates a substantial decrease.

\begin{tabular}{|c|c|c|c|c|}
\hline & A1 & $\mathrm{A} 2$ & B1 & B2 \\
\hline Coefficient of industrial growth & + & $\approx$ & $\approx$ & $\approx$ \\
\hline Coefficient of change in industry water use due to efficiency & $-\quad-$ & - & $-\quad-$ & - \\
\hline Total Industry Water Use & - & - & - & - \\
\hline Agricultural area & $-\quad-$ & $-\quad-$ & - & - \\
\hline Coefficient of change in water use for crops due to climate change & ++ & ++ & + & + \\
\hline Coefficient of change in agricultural water use due to efficiency & - & - & - & - \\
\hline Total Agriculture Water Use & $-\quad-$ & $-\quad-$ & - & - \\
\hline Population & - & + & - & - \\
\hline Coefficient of change in behaviour & $\approx$ & $\approx$ & - & - \\
\hline Coefficient of change in consumption due to climate change & + & + & + & + \\
\hline Coefficient of change in domestic water consumption due to efficiency & - & - & - & - \\
\hline Total Domestic Water Use & - & $\approx$ & $-\quad-$ & - \\
\hline
\end{tabular}

Source: Adaptaclima-EPAL project report (2011)

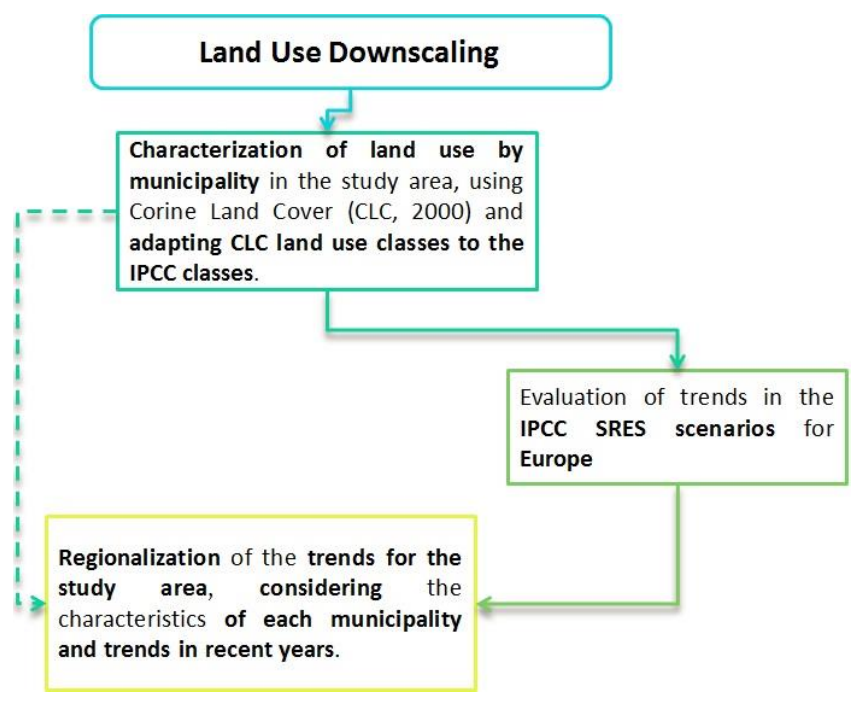

Figure 4. Land Use Downscaling Methodology. Source: Adaptaclima-EPAL project report (2011).

redistribution to the neighbouring municipalities was done by analysing recent tendencies (where the closest areas are more likely to grow) and applying the same tendencies for the local scenarios.

c. Water use efficiency - we calculated coefficients of change in consumption efficiency for each sector of water use (Fig. 3) and for each scenario considering available studies on scenarios of water consumption in Europe for the next century (Sect. 3) (e.g. Seckler et al., 1998; Märker et al., 2003; Flörke et al., 2005; Alcamo et al., 2007; Bates et al., 2008; Shen et al., 2008; Kok et al., 2009); d. Behaviour and water pricing policies - we calculated a coefficient of change in consumption due to changes in behaviours and policies for each sector of water use and each scenario considering the studies referred under (c);

e. Climate - we calculated a coefficient of change in consumption due to climate change for each scenario and for each sector considering the available climate scenarios for the study area and correlations obtained between consumption rates and climate (SIAM II, 2006; EPAL, unpublished data).

\subsection{Water use projections}

None of the studies which produced scenarios for water use in Europe for the 21st century could be directly applied to this region for three different reasons. Firstly, these studies use different assumptions and scenarios. For example, Shen et al. (2008) and Märker et al. (2003) do not consider changes considered in the SRES-like reductions of agricultural area in all scenarios, evaluating only the changes in consumption as a function of changes in climate and behaviour. Secondly, they present scenarios for different time periods. For example, Flörke et al. (2005) presents scenarios only for the 2000 2030 period. And the third reason is that some of these studies do not consider local characteristics and different dynamics between the different European countries.

Analysis of those studies was done to assess the general trends presented but with the intention of applying them to the SRES scenarios and the real situation of the study area. Regardless of the study, general trends could be identified (see also Table 1): 
1. Changes in land use, agricultural and industrial production are major forces of changes in water consumption (Mark et al., 2003; Houghton-Carr et al., 2008). All SRES scenarios indicate a reduction of the agricultural area (Table 1, Sect. 2);

2. The effects of global warming increase the need for both domestic and agriculture water consumption (Bates et al., 2008). However, these increases should be small, around $5 \%$ in $50 \mathrm{yr}$ (Bates et al., 2008). Scenarios A1 and A2 have the highest temperature increases (and larger extensions of dry periods) and thus the largest increases in water consumption needs (Table 1);

3. Technologies and behaviours might have effects on water consumption. It could drop in all sectors due to technological developments, such as increases in recycled water, improvements in irrigation efficiency and reduction of losses (Mark et al., 2003; Flörke et al., 2005; Kok et al., 2009). Technological improvements will be higher in scenarios A1 and A2. These trends are forced by worsening water shortages. According to Kok et al. (2009), it is likely that the increasing water scarcity in the southern countries of Europe will lead national governments to implement more efficient water rates, helping to reduce demand. The EU will impose more savings and water recycling, as well as sustainable urban drainage systems on a large scale for cities that are in water stress (especially in scenarios A2 and B1). The same authors reported the possibility of using desalination in coastal areas around the Mediterranean to provide water to some metropolitan areas. Water markets provide higher levels of funding for the government to invest in water saving devices at different scales (family, neighbourhood, city, etc.) (Kok et al., 2009). In B1 and B2 scenarios, there will be a tendency to improve water sustainability, reducing waste and reducing consumption per capita;

4. The evolution of population will also have influence in water consumption. This will decrease in all scenarios except A2.

Scenarios were produced for the whole study area (106 municipalities) for water use in the domestic, agriculture, industry and services sectors. Scenarios were also produced for the sub-area supplied by EPAL (34 municipalities) and for the municipalities for which we had data for water use by sector (Lisbon and Batalha). For each sector the following formula was used. Values for each parameter in the formula were obtained considering available publications.

$C$ Scenario $X_{t}=C_{\mathrm{b}} \cdot \Delta$ Sector $_{t} \cdot E_{t} \cdot$ Comp $_{t} \cdot$ Clima $_{t}$

where $C$ Scenario $X_{t}$ is the consumption in the scenario $X$ and year $t, C_{\mathrm{b}}$ is the consumption of water in the base year, $\Delta$ Sector $_{t}$ is the net change in the demand sector between the
Population evolution for the study area

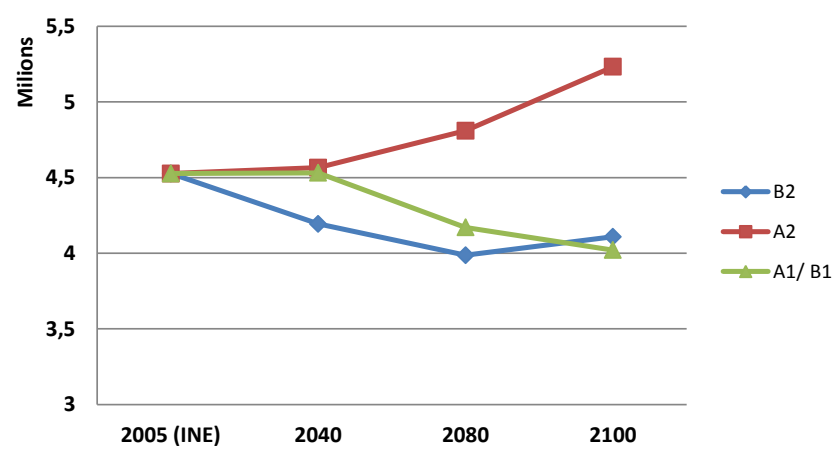

Figure 5. Population local scenarios. Source: Adaptaclima-EPAL project report (2011).

base year and year $t$ (e.g. change in population, agricultural area or industrial activity), $E_{t}$ is the coefficient of efficiency gains between the base year and year $t$, Comp $_{t}$ is the coefficient of change in behaviour between the base year and year $t$, and Clima $_{t}$ is the coefficient of change in consumption due to changes in climate between the base year and year $t$.

\section{Results and discussion}

In Table 1 we compiled the main trends in the forcing factors (land use, population, climate, efficiency, behaviour, politics) which affect water use. Only one scenario (A2) indicates an increase in the resident population of the study area of around $16 \%$ by the end of the century (Fig. 5). The remaining scenarios indicate a reduction in the population from 6 to $8 \%$. All scenarios, but especially A1, indicate a reduction in agricultural area and an increase in urban area (Fig. 6).

The main trends of the SRES for land use changes in Europe have been identified in several publications (e.g. Schröter et al., 2005; Verburg et al., 2006; Rounsevell et al., 2006; IPCC, 2007) and are summarised in Table 3. All scenarios, but especially $\mathrm{A} 1$, show a significant reduction in agricultural area and an increase in urban area.

Comparing the results for our local scenarios in the Fig. 6 and the SRES European tendencies from different authors (Schröter et al., 2005; Verburg et al., 2006; Rounsevell et al., 2006; IPCC, 2007) from Table 2, can be concluded that our local scenarios coincide with the urban and agriculture land use, but not in grassland. Our results show that this last type of land use will diminish while the European SRES tendencies for grassland will be maintained on the same level.

Regardless of the scenario, water use will progressively be reduced until 2100 (Table 4). These reductions are mainly due to increased water use efficiency and a reduction in irrigated land. Even if a warmer and drier future climate will lead to a rise in water demand for irrigation and for domestic use, none of the scenarios showed an increase in water use. Even when we consider a large increase in population 
Table 2. Percentage of Growth on the INE (2008) projections and scenarios of CIESIN (2002).

\begin{tabular}{lccccccc}
\hline & $\begin{array}{c}\text { CIESIN } \\
\text { B2 }\end{array}$ & $\begin{array}{c}\text { CIESIN } \\
\text { A2 }\end{array}$ & $\begin{array}{c}\text { CIESIN } \\
\text { A1 e B1 }\end{array}$ & $\begin{array}{c}\text { INE } \\
\text { central }\end{array}$ & $\begin{array}{c}\text { INE } \\
\text { low }\end{array}$ & $\begin{array}{c}\text { INE } \\
\text { high }\end{array}$ & $\begin{array}{c}\text { INE without } \\
\text { migrations }\end{array}$ \\
\hline \% total grow 2005-2060 & $-8.33 \%$ & $3.76 \%$ & $-0.86 \%$ & $-1.94 \%$ & $-15.70 \%$ & $13.47 \%$ & $-23.32 \%$ \\
\hline total grow 2005-2100 & $-6.07 \%$ & $19.61 \%$ & $-8.09 \%$ & & & & \\
\hline
\end{tabular}

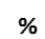

$\%$

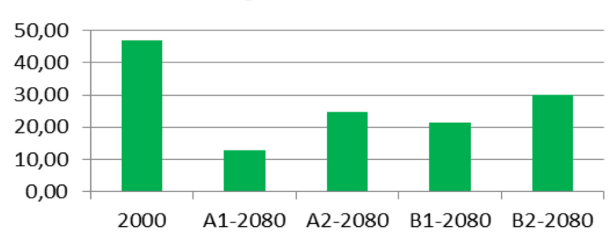

$\%$
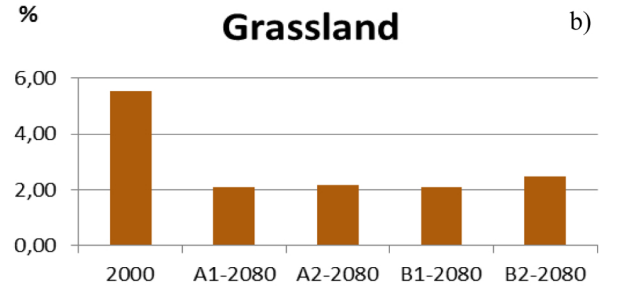

$\%$

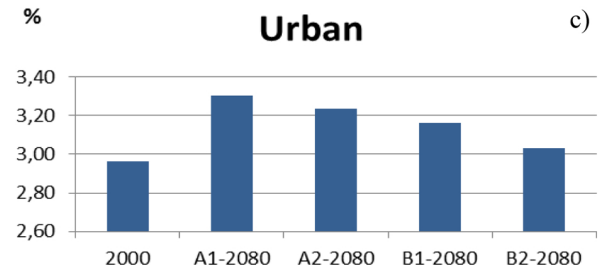

Figure 6. Local scenarios for land use change for: (a) agriculture, (b) grassland and (c) urban. Source: Adaptaclima-EPAL project report (2011).

(scenario A2), overall water consumption will be reduced. Our results thus seem to indicate that behavioural and technological factors will be the main factors in shaping future water use in the study area.

The projections of future water withdrawals presented in this paper were based on a range of assumptions regarding agricultural, industrial, and domestic water use. That is why we used four different scenarios, which indicate different possible futures in terms of socio-economic developments. All scenarios projected a reduced water use in all the analysed sectors, which increases confidence in the results. Furthermore, our results agree with several projects that model water use at a regional or global level (e.g. Seckler et al., 1998; Menzel et al., 2007). Henrichs et al. (2002), have modelled water use up to 2070 by considering a simple scenario where present water use trends were prolonged into the future and have obtained a decreased in water withdrawals in Western Europe, mainly resulting from gains in the efficiency of water use. The experiences of many coun-
Table 3. Main trends in land use changes in the SRES for Europe.

\begin{tabular}{|c|c|c|c|c|c|}
\hline & $\mathrm{A} 2$ & & $\mathrm{~A} 2$ & B1 & B2 \\
\hline Agriculture & $-\quad-$ & - & $-\quad-$ & $-\quad-$ & - \\
\hline Urban & +++ & & ++ & ++ & + \\
\hline Industry & + & & + & + & $\approx$ \\
\hline Biofuel & + & & + & ++ & + \\
\hline Forests & ++ & & + & + & +++ \\
\hline Grassland & $\approx$ & & $\approx$ & $\approx$ & $\approx$ \\
\hline Protected Areas & + & & $\approx$ & ++ & ++ \\
\hline
\end{tabular}

Table 4. Water consumption by sector in the project study area Adaptaclima-EPAL in the base year (2000) and scenarios (percent of base year values) for 2080 .

\begin{tabular}{llllll}
\hline & Base year $\left(\mathrm{m}^{3)}\right.$ & $\mathrm{A} 1$ & $\mathrm{~A} 2$ & $\mathrm{~B} 1$ & $\mathrm{~B} 2$ \\
\hline Agriculture $^{1}$ & $1443548957 \mathrm{~m}^{3}$ & $22.7 \%$ & $46.6 \%$ & $37.5 \%$ & $52.2 \%$ \\
Industry $^{2}$ & $2194069 \mathrm{~m}^{3}$ & $60.2 \%$ & $59.4 \%$ & $28 \%$ & $58.3 \%$ \\
Domestic $^{2}$ & $237702531 \mathrm{~m}^{3}$ & $87.6 \%$ & $98.3 \%$ & $48.7 \%$ & $49.8 \%$ \\
Services $^{2}$ & $6466211 \mathrm{~m}^{3}$ & $65.7 \%$ & $63.9 \%$ & $48.7 \%$ & $74.1 \%$ \\
\hline
\end{tabular}

${ }^{1}$ Baseline data: National Water Plan 2001, Corine Land Cover $2000 ;{ }^{2}$ Baseline data: INSAAR (2007), Corine Land Cover (2000).

tries show that water use intensity decreases after reaching a saturation amount, mainly due to industrial restructuring and water use efficiency improvements in production processes (Shen et al., 2008). Thus, although projected changes in water withdrawals strongly depend on the assumptions regarding socio-economic factors such as economic and industrial growth (Henrichs et al., 2002), which are largely uncertain, it seems that most scenarios indicate the same long-term trends in reduction of water use.

However, these results need to be considered carefully, also taking into account scenarios of climate and hydrological change. In Portugal, water use is highly correlated to temperature, and the warm season is also the dry season, with higher consumption rates. Therefore there is already some predisposition to water stress, especially in the south of the continental territory and during the th summer months. During the 20th century there has been a clear trend towards drier conditions, with decreases in rainfall and moisture availability in most Mediterranean regions; severe drought episodes (from both meteorological and hydrological contexts) have become more frequent and persistent, namely in the Iberia area (Sousa et al., 2011). In Portugal 
the total annual precipitation has been considerably reduced during the last decades as it rained for less number of days (SIAM II, 2006). Global climate models project a decrease in precipitation, increases in temperature and evapotranspiration, and an enlarged dry season for the study area (SIAM II, 2006). Our results support that socioeconomic changes may reduce water consumption, and therefore the risk of increased water stress due to climate change may be lower than previously expected.

\section{Conclusions}

The results of this study show that all different scenarios indicate reductions in water use in the study area. One of the main results is that behavioural and technological factors are determinant in shaping future water use in the study area. In Portugal, water use inefficiency corresponds to about $41 \%$ of the total withdrawals as referred to in the National Water Plan (2001). Thus, it is not surprising that there can be enormous gains in water efficiency, especially in the agricultural and industrial sectors.

The scenarios are a useful framework for thinking about the future and a fundamental step for EPAL to prepare a longterm adaptation strategy to climate change which is meant to contribute to the reduction of vulnerability of different future societies. EPAL's successful adaptation to climate change is vital for economic activity and the local population. The tasks that look at the impacts on the resources (quantity and quality of water) will also need to be taken into account in the process, so that the adaptation occurs in a sustainable way. To build a consistent strategy for climate change adaptation, both climate and socioeconomic scenarios are important, while socioeconomic scenarios can decrease the probability of decision failures.

Acknowledgements. This study was supported by EPAL. We are thankful to EPAL's Climate Change working group, who has supplied valuable information. We are also thankful to Nuno Grosso, Mário Pulquério, David Avelar and Tiago Lourenço for their contributions in this project.

Edited by: L. Rietveld

\section{References}

Aguiar, R. and Santos, F. D.: MISP, Energia e Emissões de Gases com Efeito de Estufa: Um Exercício de Prospectiva para Portugal até 2070. Projecto MISP: Mitigation Strategies in Portugal, Fundação Calouste Gulbenkian and Instituto D. Luis, Lisboa, 48 pp., 2007.

Alcamo, J., Flörke, M., and Märker, M.: Future long-term changes in global water resources driven by socio-economic and climatic changes, Hydrolog. Sci. J., 52, 247-275, doi:10.1623/hysj.52.2.247, 2007.
Bates, B. C., Kundzewicz, Z. W., Wu, S., and Palutikof, J. P. (Eds.): Climate Change and Water. Technical Paper of the Intergovernmental Panel on Climate Change, IPCC Secretariat, Geneva, 210 pp., http://www.ipcc.ch/pdf/technical-papers/ccw/chapter3 pdf (last access: December 2010), 2008.

Boland, J. J.: Water Supply and Climate Uncertainty, Water supply planning practice in the U.S. Universities Council on Water Resources: 112, http://ucowr.org/files/ Achieved_Journal_Issues/V112_A10Water\%20Supply\%20and\% 20Climate\%20Unvertainty.pdf (last access: October 2011), 1998.

CIESIN (Center for International Earth Science Information Network): Country-level Population and Downscaled Projections, http://www.ciesin.columbia.edu/datasets/downscaled (last access: 2 December 2010), 2002.

CLC (Corine Land cover): Carta de Ocupação do solo revista, http:// www.igeo.pt/e-IGEO/egeo_downloads.htm (last access: January 2011), 2000.

EEA, JRC and WHO: Impacts of Europe's changing climate - 2008 indicator-based assessment, European Environment Agency, Copenhagen, 2008.

Flörke, M., Isoard, Stéphane, I., and Alcamo, J.: Outlook on Water Use in Europe in 2030, Environmental Info 2005 (Brno) Masaryk University Brno, ISBN: 80-210-3780-6, 57-62, 2005.

Graffin, S. R., Rosenzweig, C. R., Xing, X., and Yetman, G.: Downscaling and Geo-spatial Gridding of Socio-Economic Projections from the IPCC Special Report on Emissions Scenarios (SRES), CIESIN, Center for Climate Systems Research, Columbia University, 2004.

Henrichs, T., Lehner, B., and Alcamo, J.: An Integrated Analysis of Changes in Water Stress in Europe, Center for Environmental Systems Research, University Kassel, Germany, Integrated Assessment, 3, 15-29, 2002.

Houghton-Carr, H. A., Fry, M. J., and Farquharson, F. A. K.: Driving forces of future water availability and water use within $\mathrm{Eu}-$ rope, BHS 10th National Hydrology Symposium, Exceter, 2008.

INAG: Plano Nacional da Água, Instituto Nacional da Água, Ministério do Ambiente, do Ordenamento do Território e do Desenvolvimento Regional, http://www.inag.pt/index.php?option= com_content\&view $=$ article $\& i d=9 \&$ Itemid $=69$ (last access: December 2010), 2001.

INE: Anuário Estatístico 2005, Instituto Nacional de Estatística, available at: http://www.ine.pt/xportal/xmain? xpid=INE\&xpgid=ine_destaques\&DESTAQUESdest_boui= 74644\&DESTAQUESmodo=2; (last access: December 2010), 2006a.

INE: Estimativas Provisórias de População Residente Portugal 2005, NUTS II, NUTS III e Municípios, ISSN: 1645-8389, http: //www.ine.pt (last access: December 2010), 2006b.

INE: Projecções de População Residente em Portugal 2008-2060 - Metodologia, Instituto Nacional de Estatística - Departamento de Estatísticas Demográficas e Sociais (http://www.ine.pt/xportal/xmain?xpid= INE\&xpgid=ine_publicacoes\&PUBLICACOESpub_boui= 6188154\&PUBLICACOESmodo=2), 2008.

IPCC: Emissions Scenarios. A Special Report of Working Group III of the Intergovernmental Panel on Climate Change, Cambridge University Press, Cambridge, 2000. 
IPCC: IPCC Fourth Assessment Report (AR4), edited by: Watson, R. T. and the Core Writing Team, IPCC, Geneva, Switzerland, 184 pp., 2007.

INSAAR: Inventário Nacional de Sistemas de Abastecimento de Águas e Águas Residuais, available at: http://insaar.inag. pt/index.php?id=21\&year=2007 (last access: December 2010), 2007.

Kok, K., Vliet, M., Bärlund, I., Sendzimir, J., and Dubel, A.: First ("first-order") draft of pan-European storylines results from the second pan-European stakeholder workshop, SCENES Deliverable 2.6, Wageningen Universitiy, Wageningen, http://www.environment.fi/download.asp?contentid= 113374\&lan=en (last access: April 2011), 2009.

Märker, M., Flörke, M., Vassolo, S., and Alcamo, J.: Preliminary assessment of IPCC-SRES scenarios on future water resources using the WaterGAP 2 model, Center of Environmental Systems Research, University of Kassel, http://www.mssanz.org.au/ MODSIM03/Volume_01/A07/03_Maerker.pdf (last access: April 2011), 2003.

Menzel, L., Flörke, M., Matovelle, A., and Alcamo, J.: Impacts of socio-economic development and climate change on water resources and water stress, Proc. 1st International Conference on Adaptative and Integrative Water Management (CAIWA), 2007.

O'Neill, B., Balk, D., Brickman, M., and Ezra, M.: A guide to global population projections, Demogr. Res., 56, 203-288, doi:10.4054/DemRes.2001.4.8, 2001.

Rounsevell, M. D. A., Reginster, I., Araújo, M. B., Carter, T. R., Dendoncker, N., Ewert, F., House, J. I., Kankaanpää, S., Leemans, R., Metzger, M. J., Schmit, C., Smith, P., and Tuck, G.: A coherent set of future land use change scenarios for Europe, Agr. Ecosyst. Environ., 114, 57-68, doi:10.1016/j.agee.2005.11.027, 2006.

Schröter, D., Cramer, W., Leemans, R., Prentice, I. C., Araújo, M. B., Arnell, N. W., Bondeau, A., Bugmann, H., Carter, T. R., Gracia, C. A., de la Vega-Leinert, A. C., Erhard, M., Ewert, F., Glendining, M., House, J. I., Kankaanpää, S., Klein, R. J. T., Lavorel, S., Lindner, M., Metzger, M. J., Meyer, J., Mitchell, N. W., Reginster, T. D. I., Rounsevell, M., Sabaté, S., Sitch, S., Smith, B., Smith, J., Smith, P., Sykes, M. T., Thonicke, K., Thuiller, W., Tuck, G., Zaehle, S., and Zierl, B.: Ecosystem Service Supply and Vulnerability to Global Change in Europe, http://www.sciencemag.org/content/suppl/ 2005/11/21/1115233.DC1/Schroter.SOM.REV.pdf (last access: January 2011), 2005.
Seckler, D., Molden, U. A. D., Silva, R., and Barker, R.: World water demand and supply, 1990 to 2025: Scenarios and issues. Research Report 19. Colombo, Sri Lanka, International Water Management Institute, ISBN 92-9090354-6, $\quad$ http://www.iwmi.cgiar.org/Publications/ IWMI_Research_Reports/PDF/PUB019/REPORT19.PDF (last access: January 2011), 1998.

SIAM II: Alterações Climáticas em Portugal - Cenários, Impactos e Medidas de Adaptação, Projecto SIAM, edited by: Fase II, F D. S. and Miranda, P., Editorial Gradiva, Lisbon, http://siam.fc. ul.pt/siamII_pdf/SIAMII.pdf, 2006.

Shen, Y., Oki, T., Utsumi, N., Kanae, S., and Nahasaki, N.: Projection of future world water resources under SRES scenarios: water withdrawal, Hydrolog. Sci. J., 53, 11-33, doi:10.1623/hysj.53.1.11, 2008.

Sousa, P. M., Trigo, R. M., Aizpurua, P., Nieto, R., Gimeno, L., and Garcia-Herrera, R.: Trends and extremes of drought indices throughout the 20th century in the Mediterranean, Nat. Hazards Earth Syst. Sci., 11, 33-51, doi:10.5194/nhess-11-33-2011, 2011.

van Vuuren, D. P., Lucas, P. L., and Hilderink, H. B. M.: Downscaling drivers of global environmental change - Enabling use of global SRES scenarios at the national and grid levels, Report 550025001, Netherlands Environmental Assessment Agency, http://www.rivm.nl/bibliotheek/rapporten/ 550025001.pdf (last access: January 2011), 2007.

van Vuuren, D. P., Smith, S. J., Riahi, Keuwan: Downscaling socioeconomic and emissions scenarios for global environmental change research: a review, John Wiley \& Sons, Ltd, 1, 393-404, doi:10.1002/wcc.50, 2010.

Verburg, P. H., Schulp, C. J. E., Witte, N., and Veldkamp, A.: Downscaling of land use change scenarios to assess the dynamics of European landscapes, Agr. Ecosyst. Environ., 114, 39-56, doi:10.1016/j.agee.2005.11.024, 2006. 